\title{
DYNAMIC FOCUSING OF ELECTROACOUSTIC ARRAYS IN NON-DESRUCTIVE CONTROL COMPOSITE MATERIALS
}

\author{
Eugenijus Pileckas \\ Antanas Gustaitis Aviation Institute of Vilnius Gediminas Technical University \\ Rodūnès kelias 30, LT-02187 Vilnius, Lithuania \\ E-mail:eugenijus.pileckas@vgtu.lt
}

Received 05 May 2010, accepted 20 May 2010

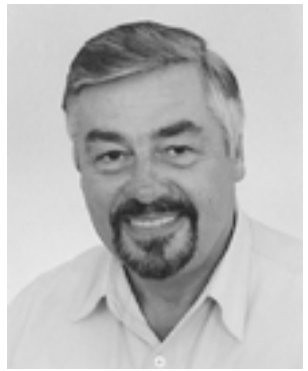

Eugenijus PILECKAS, Prof Dr Habil

Date and place of birth: 1941, Trakai, Lithuania.

Education: 1965 - Kaunas polytechnics. 1974 - PhD, 1985 - D Sc, 1987- Prof.

Experience: Head of Department of Ultrasonic Medicine Technology in Radio Measurements Scientific Researches Institute 1965-1986. Head of Department of Electronics in Kaunas Technology University 19861991. Director General of "Elita" - Institute of Scientific Researches in Electronics 1991-1998. Professor in Antanas Gustaitis Aviation Institute of Vilnius Gediminas Technical University, Department of Avionics - since 1998.

Awards: laureate of two state science prizes.

Publications: author of 2 monographs, 3 books, 80 inventions, several hundreds of articles and conference papers.

\begin{abstract}
Nowadays the application possibilities for composite materials for aviation are increasing, and monitoring their quality during production and exploitation is becoming more and more relevant. Acoustic non-destructive control technologies provide promising possibilities for monitoring and analysing the characteristics and parameters of composites. This paper discusses an acceptable modelling method based on acoustic images of composite material analysis using a dynamic beam focusing method of an acoustic antenna array.
\end{abstract}

Keywords: composite materials, ultrasonic waves, dynamic focusing of antenna array acoustic beam.

\section{Introduction}

Composite materials used in aviation have been widely analysed (Paramonova et al. 2004). For this purpose, non-destructive control techniques more and more often use ultrasonic echoscopy systems where an acoustic image is modelled by scanning two-dimensional objects of investigation and selecting real time signals.

In that way, a type of acoustic sectional view (Домаркас $u$ дp. 1988) of objects B or C is formed using mechanical actuators (Green 1990) or acoustic antenna arrays with controlled beam (Ness et al. 1996). In the first case however, view formation is quite slow, and there are problems with technological acoustic array control in the second case.

A case of compromise is when ultrasonic scanning is performed mechanically in one coordinate, and in the other coordinate scanning is performed using electronbeam control of a linear acoustic antenna array.
Ultrasonic beam dynamic focusing principle (Paramonova et al. 2003) of scanning electroacoustic array can be used for forming an image produced by echoscope of the composite material being investigated. The image is independent of ultrasonic beam shape of the scanning object. The essence of the dynamic focusing of the acoustic array beam which receives information is that the overall array echo signal is accepted from the ultrasonic beam focus area by shifting accordingly real time delay of echo signals in the separate piezo element arrays. Processing of such received echo signals can be obtained gradually or discretely (Fig 1). In the latter case, transitions are used for changing the focusing distance.

\section{Focusing methodology}

Below we will analyse how to choose the optimal quantity of acoustic array focusing areas with scanning array aperture to reach the even width of acoustic array beam receiving echo signals with the help of focusing. 
Now we will analyse a circular piezo element array (Fig 1) that has $\mathrm{N}$ piezo elements spaced straight in a plane with an interval between $\mathrm{d}$ levels of element centres. When electrically controlled array $\mathrm{i}(\mathrm{i}=1,2,3 \ldots \mathrm{N})$ piezo element is used in focusing, it must be switched to processing process in delayed time estimated in the following equation:

$$
t_{s v, n \max }=\frac{r_{f}}{c}\left[1-\sqrt{1+\frac{x_{n}^{2}}{r_{f}^{2}}-2} \frac{x_{n}}{r_{f}}\left(\sin \gamma_{0}-\sin \gamma\right)\right] .
$$

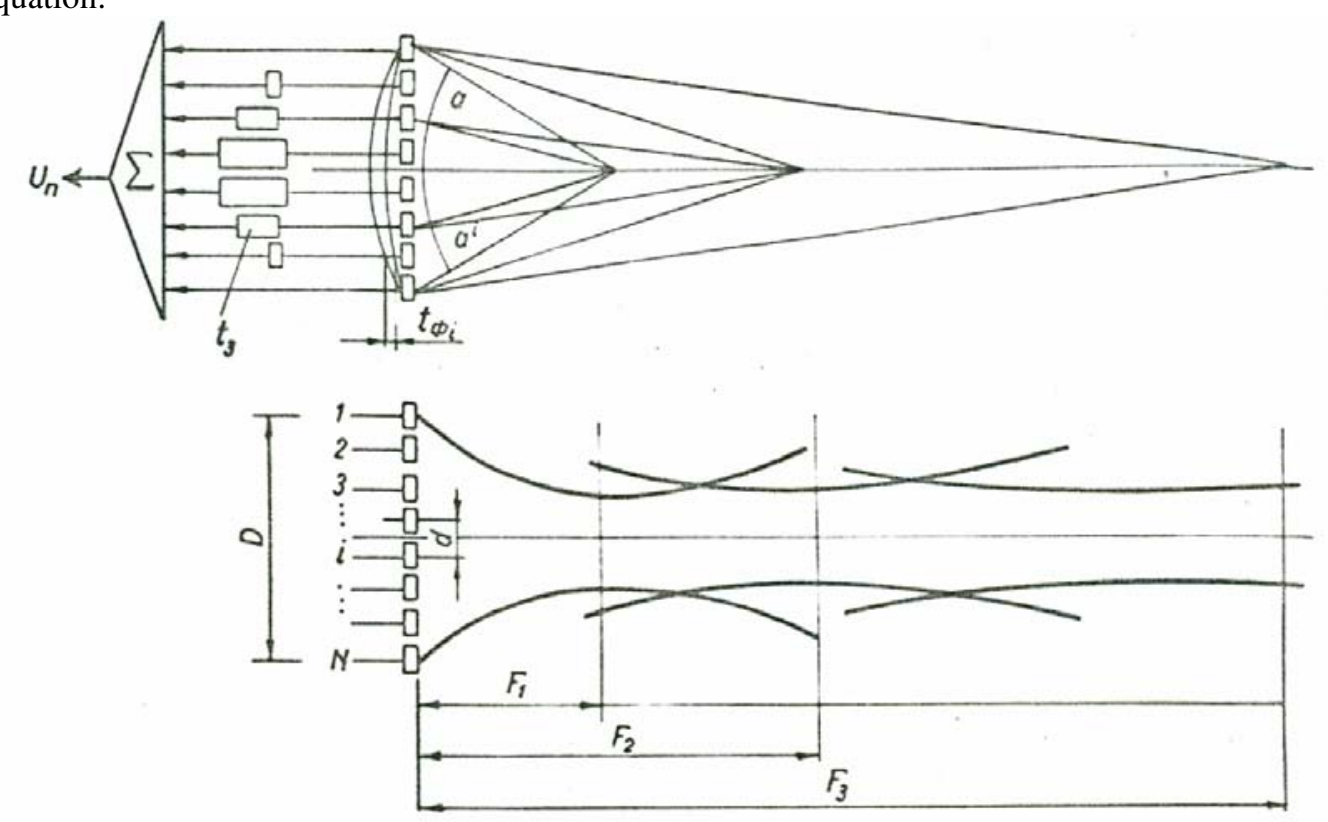

Fig 1. Explanation of application of antenna array acoustic beam dynamic focusing: $t_{s}$ and $t_{f_{1}}$ - delay values of $i$ piezoelement echo signals, overall and focusing; $F_{1}, F_{2}, F_{3}$ - focusing distances; $U_{n}$ - total echo signal in the output of piezoelement array; $D$ diameter of array aperture

It is convenient to enter generalized value $K$ determining the following ultrasonic beam focusing level for focusing systems:

$$
K=\frac{D}{4 \lambda F},
$$

where: $\lambda$ - ultrasonic wavelength; $F=r_{f}$ - focus distance; $D=N \times d$-focusing array aperture.

Value $K$ expresses the relative focusing coefficient of the focusing array. The coefficient is normalized by duration of near zone linked with aperture value and ultrasonic wavelength $\lambda$ in the environment of investigation when $K \gg>1$ focusing effect is large and the duration of the focusing zone is restricted to the focal point area. When $K$ is equal to 1 the focal zone increases, and therefore focusing level decreases. Finally, when $K<<1$ there is almost no focusing. If we can aperture $D$ and grating pitch $d$ express by wavelength $\lambda$ and focus distance $r_{f}$ by aperture $D$, as a result we can estimate effective zones, when $K>>1$ for scanning aperture and working ultrasonic frequency in expression (2).

The measurements performed show that it is necessary to shift the size of the array aperture in a way of decreasing it and approaching the focus in order to reach focusing with permanent coefficient $\mathrm{K}$ in the whole ultrasonic beam length. As a result, the focal distance changes and the duration of focal zone area changes as well. That provides a possibility to choose optimal focusing distances where the quasi-collimated ultrasonic beam (Fig 1) is reached. Furthermore, the choice of focusing array aperture size is related to step d, with the amount of piezoelements in the aperture $\mathrm{N}$, and with the multichannelism of the focusing distance control scheme. Value $d$ is related to discretion of commutative ultrasonic scanning in the linear arrays and with optimal width and thickness ratio of array piezoelements in the scanning working ultrasonic frequency.

Linear and circular arrays impulsive directivity characteristics have been investigated for reluctance mentioned, and as a result ultrasonic beam parameter dependence on the parameters and focusing distance was estimated. The investigations conducted showed that the width of the ultrasonic beam in the focus faintly depends on aperture size determined by relative focusing depth. What is more, when focusing is in the near zone $r_{f} \leq 4 D_{\lambda}$, beam width remains stable practically in the entire scanning aperture range $D_{\lambda}$ ( $D_{\lambda}$ values expressed by wavelength $\lambda$ in the scanning frequency $f_{0}$, which were chosen according to the condition that array aperture $\mathrm{D}$ is stable in the scanning frequency range from $0,88 \mathrm{MHz}$ until 4,5 $\mathrm{MHz}$ as given in figure 2 .

The beginning of the focal zone (Fig 3) almost depends on focusing depth and aperture value in terms of a straight line, and at the same moment rises when these values also increase. Equability stability of ultrasonic beam width in the sufficiently large axis directivity distance can be reached with a number $D_{\lambda}$ (within the 
pale from three until five), of not high aperture finite values. Also the stability of ratio $r_{f} / D_{\lambda}$ remains the same.

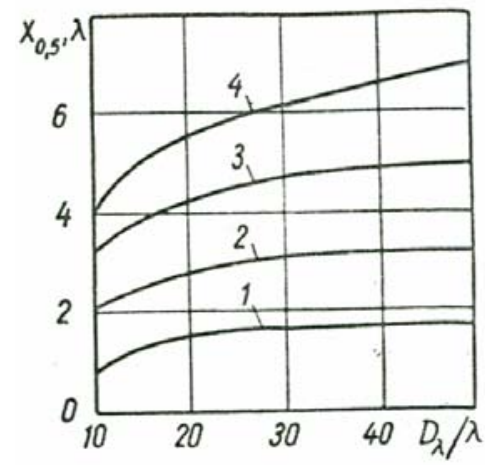

Fig 2. Width of aperture signal impulse of focused linear array:

$$
1-r_{f} / D_{\lambda}=1 ; 2-3 ; 3-5 ; 4-8
$$

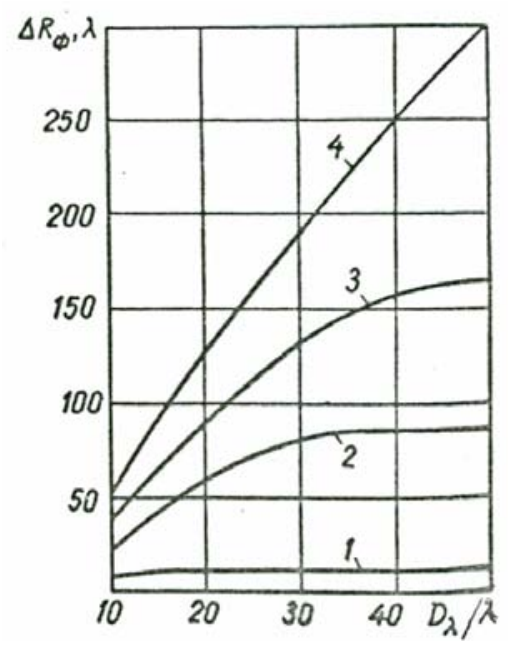

Fig 3. Focal zone length of linear array:

$$
1-r_{f} / D_{\lambda}=1 ; 2-3 ; 3-5 ; 4-8
$$

The focusing properties of linear and circular arrays coincide in terms of quality. Some discrepancies appear in relative focusing cases of large circular array apertures, causing the widening (up to $20 \%$ ) of aperture signal impulse and curve character changes that are shown in figures 2 and 3. The explanation of that is the central ring impact on forming the ultrasonic beam is not very strong for the cases mentioned due to the relatively small area in comparison with the central ring area, which is more deviated. Interestingly, actual array focus distance $Z_{\max }$ shifts in respect to geometrical focus $r_{f}$ (Fig 4). Actual focus moves to the approaching side to aperture, i.e. $\frac{Z_{\max }}{r_{f}}<1$ for the circular arrays, and for linear arrays it moves in the opposite direction - to the aperture side which is receding $\frac{Z_{\max }}{r_{f}}>1$. Additionally, the relative focus shift curve crosses the line equal to one when linear arrays are by the larger apertures (Fig 4 b). As a result, geometrical and actual focal coincidence can be reached when sufficient linear array focus is chosen for each aperture value. Unfortunately, circular arrays are not able to reach that coincidence.
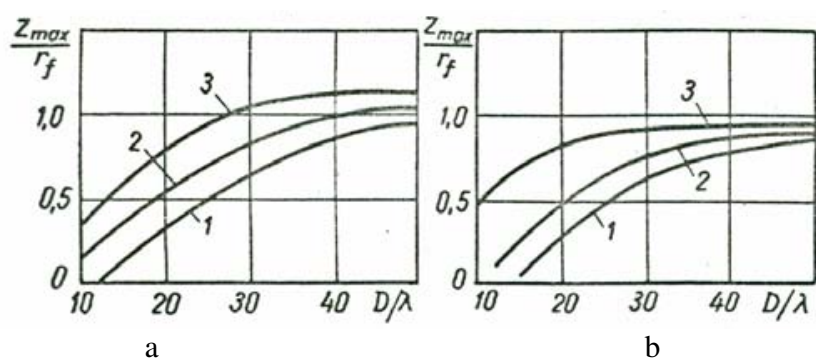

Fig 4. Relative focal distance of linear (a) and (b) circular arrays: $1-r_{f}=80 \lambda ; 2-60 \lambda ; 3-240 \lambda$

It is also worth emphasising that in the pulsed working mode when spatial impulse duration does not exceed the aperture value, in no case do we notice vibrating character in the near array zone that is peculiar for uninterrupted working mode. In the case when the focal distance changes and the aperture is stable in the axis of the ultrasonic beam, the pressure module reaches the maximum in the focal area and the increased pressure zone remains in the whole focal zone length, decreasing almost in a straight direction in terms of increase in focal distance. To obtain vibrant pressure module stability in the axis of the ultrasonic beam, it is necessary to change not only $\mathrm{D}$ value but also equivalent beam width stability in the case of its hold. That is well presented in the example given in figure 5, illustrating vibrant pressure module envelopes in the array axis when its aperture rises by the stable relative focusing coefficient $\mathrm{K}$.

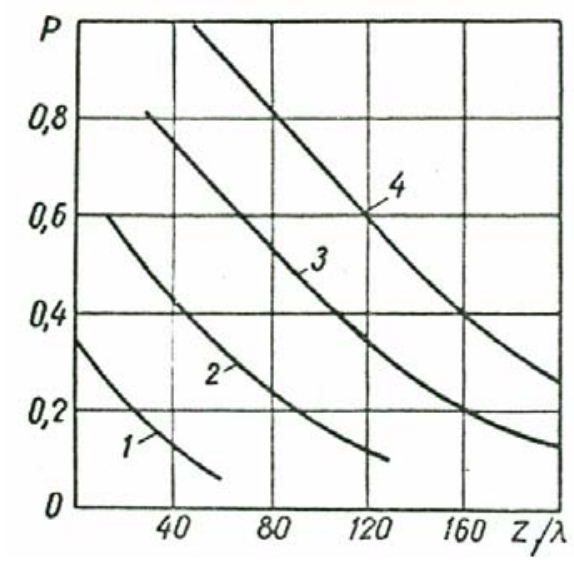

Fig 5. Normative linear arrays of vibration pressure peak module waveform focus $(\mathrm{k}=2)$ :

$$
1-D_{\lambda}=12 ; 2-14 ; 3-36 ; 4-48
$$

Curves that characterize the required diffractionamplitude corrections when the focus occurs are presented in figure $6 \mathrm{a}$ and $\mathrm{b}$. As a result of comparison of the given corrected dependency numerical values, the maximum correction values slightly decrease when focus distance $r_{f}$ rises. The reason for that is that due to axial array symmetry and focus coming, axial concentration of 
ultrasonic wave pressure rises. The concentration belongs to the input aperture that is not reachable in the linear arrays at that level due to their aperture asymmetry.
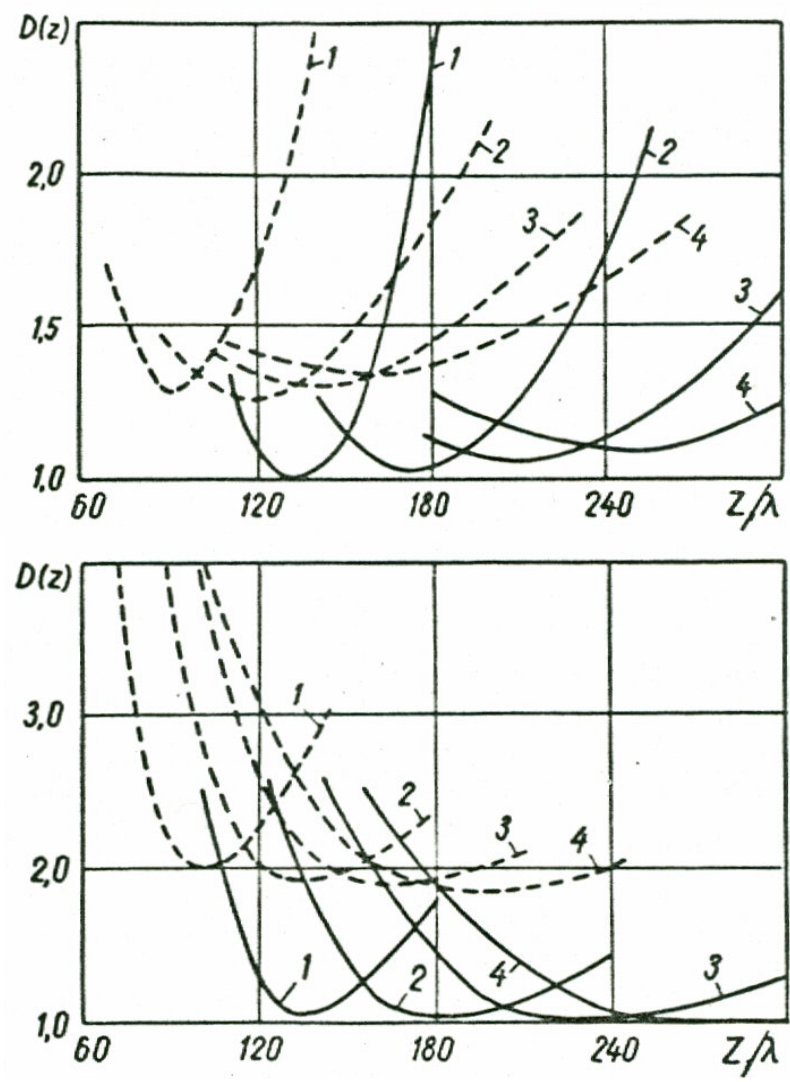

Fig 6. Diffraction corrections for focused linear (a) and circular (b) arrays

(d = 1,5 mm, $D_{\lambda}=30-$ continuous beam, $D_{\lambda}=45-$ dotted line): $1-r_{f} / D_{\lambda}=3 ; 2-4 ; 3-5 ; 4-6$

\section{Experiments}

Experiments were performed with the theoretical results discussed, showing that when dynamic focusing method is realized in the ultrasonic non-destructive control instruments, their resolution and measurement precision can increase 2 to 3 times.

That is proved by the experimental results given below in figure 7 , where ultrasonic beam parameters in the measurement system with linear electroacoustic arrays are practically realized. Figure 8 represents echograms obtained by diffusion reflectors using a special test object.

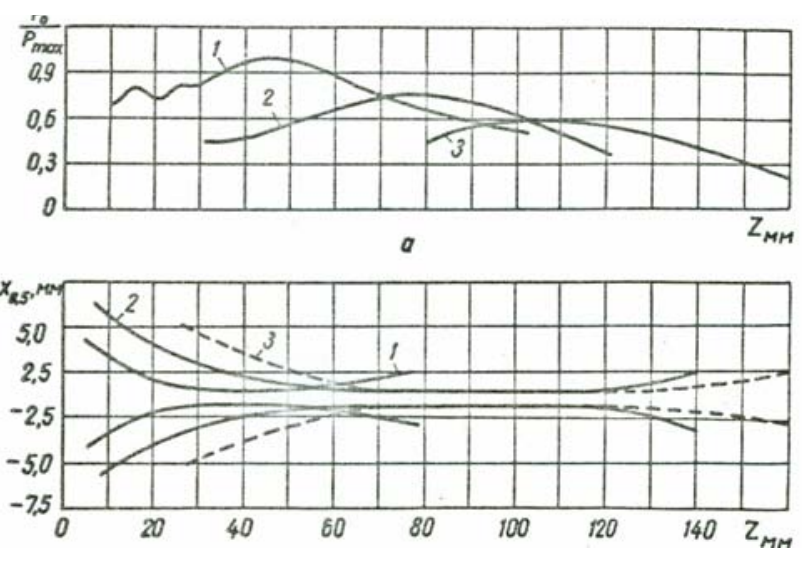

Fig 7. Vibrant pressure module distribution (a) in the ultrasonic beam axis (b) when linear arrays $\left(\mathrm{d}=1,5 \mathrm{~mm}, f_{0}=3,5 \mathrm{MHz}\right)$

during dynamic focusing: $1-N_{1}=8, F_{1}=45 \mathrm{~mm}$;

$2-N_{2}=12 \quad F_{2}=75 \mathrm{~mm} ; 3-N_{3}=16 \quad F_{3}=115 \mathrm{~mm}$.
A

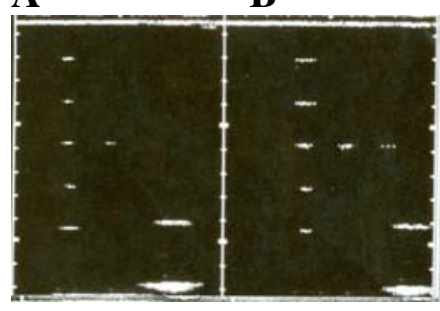

C

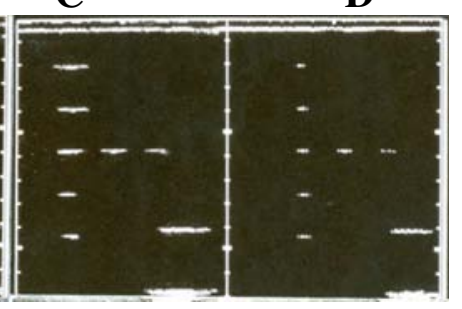

Fig 8. Echoscopy of small wire-shape diffusion reflector distances $(\Delta z=20 \mathrm{~mm}$ ) distributed in the water according to the same depths when ultrasonic beam is being focused: $\mathrm{A}-F_{1}=45 \mathrm{~mm} ; \mathrm{B}-F_{2}=75 \mathrm{~mm} ; \mathrm{C}-F_{3}=115 \mathrm{~mm}$. D dynamic focusing

\section{Conclusion}

Echoscopy objects images of investigation may be modelled with increased resolution and minimum deviations using dynamic focusing realisation of electroacoustic arrays in the defectoscopy of composite materials. As a result, the reliability of non-destructive composite objects control objectivity is enhanced.

\section{References}

Green, R. E. Jr. 1990. Nondestructive evaluation of materials, Annual Review of Materials Science 20: 197-217.

Paramonova, A. Yu.; Kleinhofs, M. A.; Paramonov, Yu. M. 2003. The estimation of parameters of fatigue curve of composite material, Aviation 7(1): 28-35.

Paramonova, A. Yu.; Kleinhofs, M. A.; Paramonov, Yu. M. 2004. Binomial version of Markov model of fatigue life of composite with two reasons for failure, Aviation 8(2): 14-20.

Ness, S.;Charles N. Sherlock, C. N. 1996. Nondestructive Testing Overview. 2nd edition. 620 p.

Домаркас, В. Й.; Пилецкас, Э. Л. 1988. Ультразвуковая эхоскопия. Л.: Машиностроение. 276 с. 


\section{ELEKTROAKUSTINIU GARDELIU DINAMINIS FOKUSAVIMAS KOMPOZITINIU MEDŽIAGU DEFEKTOSKOPIJOJE}

\section{E. Pileckas}

S a n trauka

Vis plačiau naudojant kompozitines medžiagas aviacijoje aktualëja ir jų kokybės būsenos stebėjimas konstrukcijų gamybos ir eksploatacijos metu. Akustinès neardomosios kontrolès technologijos atveria, mūsų nuomone, perspektyvias kompozitinių medžiagų charakteristikų bei jų parametrų stebẻjimo ir tyrimo galimybes. Straipsnyje nagrinëjamas priimtinas kompozitinių medžiagų tyrimui akustinių vaizdų formavimo būdas, panaudojant akustinès antenų gardelès dinamini spindulio fokusavimo būdą.

Reikšminiai žodžiai: kompozitinès medžiagos, ultragarso bangos, antenų gardelės akustinio „spindulio“ dinaminis fokusavimas. 